not discussed. The implication is that we are being given an exhaustive list of representations of chemical weapons. But there are many omissions, major and minor. Particularly notable is the neglect of military attitudes, important in understanding why the military have been especially averse to chemical weapons. An important question here is why chemical weapons have never been assimilated into core military doctrine or practice. Generally, weapons innovations are either accepted and incorporated into standard military theory or abandoned altogether for reasons such as military utility or institutional resistance. Chemical weapons are unusual in that, although not accepted into mainstream military practices, and despite the fact that they have rarely been used, their development and acquisition have often been maintained.

Another omission is any analysis of scientific discourses, which would outline how the science of chemical weapons has been defined and developed, and indicate the particular innovation processes involved. Scientists have often been the stimulus for the development and use of chemical weapons. For example, Fritz Haber, father of nitrogen fixation, championed the first use of chemical weapons in the First World War.

The 1993 Chemical Weapons Convention could in the coming decades be the frontrunner in a growing body of arms-limiting legislation. Price's book may contribute to this process, demonstrating how weapons systems can be made political and how taboos maybe, in part, a cultural construct.

Henrietta Wilson is at the Pugwash Conferences on Science and World Affairs (British Group), Ground Floor Flat, 63A Great Russell Street, London WC1B $3 B J, U K$.

\section{Let it shine}

\section{The Fire Within the Eye: A Historical Essay on the Nature and Meaning of Light}

by David Park

Princeton University Press: 1997. Pp. 377.

$\$ 29.95, £ 24.95$

\section{William Shea}

One of the triumphs of the scientific revolution of the seventeenth century was the understanding of optical phenomena. René Descartes explained how the rainbow was produced by reflection and refraction in drops of water in the atmosphere, and Newton became famous for showing that white light is a mixture of different colours. Newton was celebrated in verse, and the admiration of his contemporaries is captured in Pope's famous epitaph: "Nature and Nature's laws lay hid in night,/God said, 'Let Newton be!' and all was light".

Nearly a century later, a group of poets met in London in the studio of the painter Benjamin Haydon on 28 December 1817. In his diary, Haydon tells us how Wordsworth, "in a strain of humour beyond description, abused me for putting Newton's head into my picture: 'a fellow,' said he, 'who believed nothing unless it was as clear as the three sides of a triangle'. And then Keats agreed that he [Newton] had destroyed all the poetry of the rainbow by reducing it to its prismatic colours. It was impossible to resist him, and we all drank 'Newton's health, and confusion to mathematics'”

Not long after this toast, Keats wrote the familiar lines in Lamia: "Do not all charms fly/At the mere touch of cold philosophy?/ There was an awful rainbow once in heaven:/We know her woof, her texture; she is given/In the dull catalogue of common things./Philosophy will clip an Angel's wings,/Conquer all mysteries by rule and line,/Empty the haunted air, and gnomed mine/Unweave a rainbow...."

The wheel of fortune had come full circle. Worshipped, almost deified, by the Augustan poets for his successful explanation of the nature of light, Newton was now damned for destroying its numinous character. This incident is a powerful reminder that light is more than something we perceive with our eyes or measure with our instruments. When the Bible says, "God is light and in him is no darkness at all", we see a metaphor, but David Park argues in this genuinely illuminating book that the author of these words may have intended them as a plain statement of fact. There were times when understanding and vision, or goodness and light, were so close that you could not slip a straw between them. But the history of thought resembles the astronomer's expanding Universe. As our mental cosmos widens, ideas once closely related spread out and become isolated and lose all connection, except, perhaps, what is remembered in a few words. Medicine once went hand in hand with astrology; little now remains of their relation except the term 'influenza', which refers to heavenly influences.

Writing for a general audience, Park avoids technical language and concentrates on thinking more than on results. He traces the development of our notions about the nature of light in a way that will interest those who know nothing about lasers as well as those who use them every day. The quest for the nature of light began with the study of vision: how does it happen that when we open our eyes our minds are filled with images of things close and far away? Why must there be light before we can see? For a thousand years people debated what the visual message is: what is it that carries the message, and does it move from the object to the eye or issue from the eye to play on the object? As late as the seventeenth century, as distinguished a natural philosopher as Descartes still believed that exceptionally gifted people (including himself) could see in the dark because their eyes

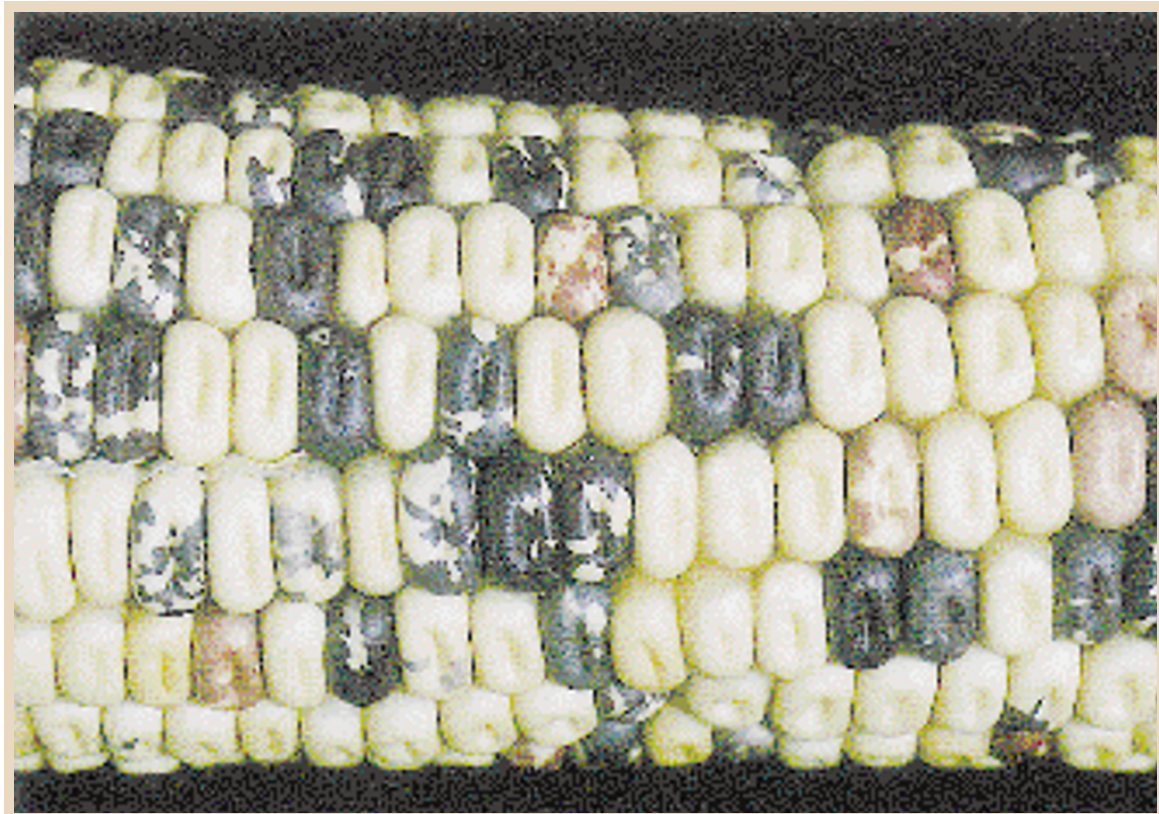

\title{
The ten chromosomes of corn
}

Mutants of Maize by M. G. Neuffer, E. H. Coe and S. R. Wessler contains more than 400 colour photographs of the diverse genetic variants of corn. First published in 1968 and long out of print, it now covers twice the number of mutants and provides detailed descriptions of mutant gene loci as well as summaries of the physical structure of cloned genes. Mutant maize genes have counterparts in most higher plant species, so the book should have a wider readership than just corn biologists. Cold Spring Harbor Laboratory Press, \$250 (hbk), \$100 (pbk). 
acted as searchlights. As a confirmation of this theory, he appealed to the overwhelming evidence that cats can see at night!

For what, indeed, is this thing we call light? It brings life to the world around us, and it is the means by which most of us see and act. At the end of the twentieth century, physicists call light a quantized electromagnetic field. But what is that? We understand the mathematical theory very well, but how to translate its rarefied jargon into the rich and specific language of the everyday world of common sense? A quantized field has a mathematical description in terms of waves or in terms of particles. It is a matter of convenience, for the two descriptions are in every way equivalent. If we want to talk about it with someone not interested in calculation, what should we say? In plain words, what is actually light? This is the story of how scientists have tried to answer this question. It is a fascinating account, brilliantly told, full of digressions that are useful because they help us to enter the intellectual and social climate where ideas about light were born. It is also a story with a moral: we come from darkness and end in darkness, but we must never stop saying, "Lead on, kindly light".

William Shea is at the Institut d'Histoire des

Sciences, Université Louis Pasteur de Strasbourg 7, rue de l'Université, 67000 Strasbourg, France.

\section{Also on history}

Einstein: A Life by Denis Brian. A wellresearched biography first published in hardback last year. Wiley, $\$ 19.95, £ 11.99$ (pbk). Galileo on the World Systems edited by Maurice A. Finocchiaro. A new abridged translation and guide. University of California Press, \$19.95 (pbk).

Equivalence and Priority: Newton Versus Leibniz by Domenico Bertoloni Meli. Includes Leibniz's unpublished manuscripts on Newton’s Principia. OUP, $£ 25$ (pbk). Reviewed by W. R. Shea in Nature 364, 681 (1993).

Victorian Science in Context edited by Bernard Lightman. Wide-ranging essays, from Maxwellian physics to science fiction to zoological taxonomy, that look at how science influenced and was influenced by the larger Victorian culture. University of Chicago Press, \$70, 255.95 (hbk); \$22.50,

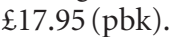

Discovering Birds: The Emergence of Ornithology as a Scientific Discipline, 1760-1850 by Paul Lawrence Farber. First published in 1982, the book begins by looking at the influence of Buffon's Histoire naturelle. Johns

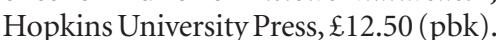

A Chronology of Medicine and Related Science by Leslie T. Morton and Robert J. Moore. Entires cover historical events; the establishment of institutions, hospitals, societies and journals; the publication of important books and papers; and biographical information for

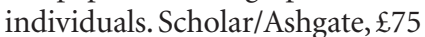

\section{Truth on the outside}

On the Surface of Things: Images of the Extraordinary in Science

by Felice Frankel and George M. Whitesides Chronicle Books: 1997. Pp. 160. \$35 (hbk), $\$ 22.95$ ( $p b k$ )

\section{Roald Hoffmann}

On reading this book one gets the immediate feeling that one's eyes and mind have truly feasted, that one holds in one's hands an obvious classic at the nexus of art and science. It's the feeling I had when I first read Primo Levi's The Periodic Table, or saw Irving Geis's protein structures, or looked at Peter S. Stevens's Patterns in Nature.

The meeting point here is of photography and surface science, the latter field itself a commons of chemistry, engineering and physics. Felice Frankel is an internationally recognized photographer, whose previous work has been in photographing landscape architecture (also surfaces, also natural and unnatural). George Whitesides is an outstanding chemist, versatile in the extreme, as savvy to the applied as he is to the pure. This modestly priced book contains about 60 photographs by Frankel, and short accompanying texts by Whitesides.

The photographs are startlingly beautiful. In fact, two readers of On the Surface of Things are likely to fall into this dialogue: "Did you see that photo of a ferrofluid, those weird spikes caught between surface tension and magnetism?" "Yes, I did. But what I liked best were the mauve and redbrown rings in the Belousov-Zhabotinsky reaction!" "Really? Did you see that film chaotically peeling off a silicon crystal?"

At the end of the book are little paragraph notes by Frankel on the photographic techniques she used. These are written in an engaging personal style, and, once one discovers them, one is drawn to reading them in tandem with each image.

Frankel's spectacular photographs are the heart of this book, to be sure. But Whitesides also surprises. First, he succeeds (in too small a font, the only design failure of this book) in explaining complex matters of spectroscopy, electronics and the properties of materials without the impediment (to some) and the crutch (to others) of mathematics. Second, he writes of surfaces evocatively, really crafting prose poems around each image.

Art is no more an accident than science. The serious play of the mind, what Immanuel Kant called "the mutual relations of the imagination and the understanding" (and the hand, and the eye), is central to both human enterprises. It is then no surprise that a different way of representing (therefore seeing) an object of scientific investigation - through the artist's sensibility - should be of scientific value. This, just as much as the sheer beauty of the images, is the importance of what Frankel and Whitesides are doing.

Roald Hoffmann is in the Department of

Chemistry, Cornell University, Ithaca, New York 14853-1301, USA.

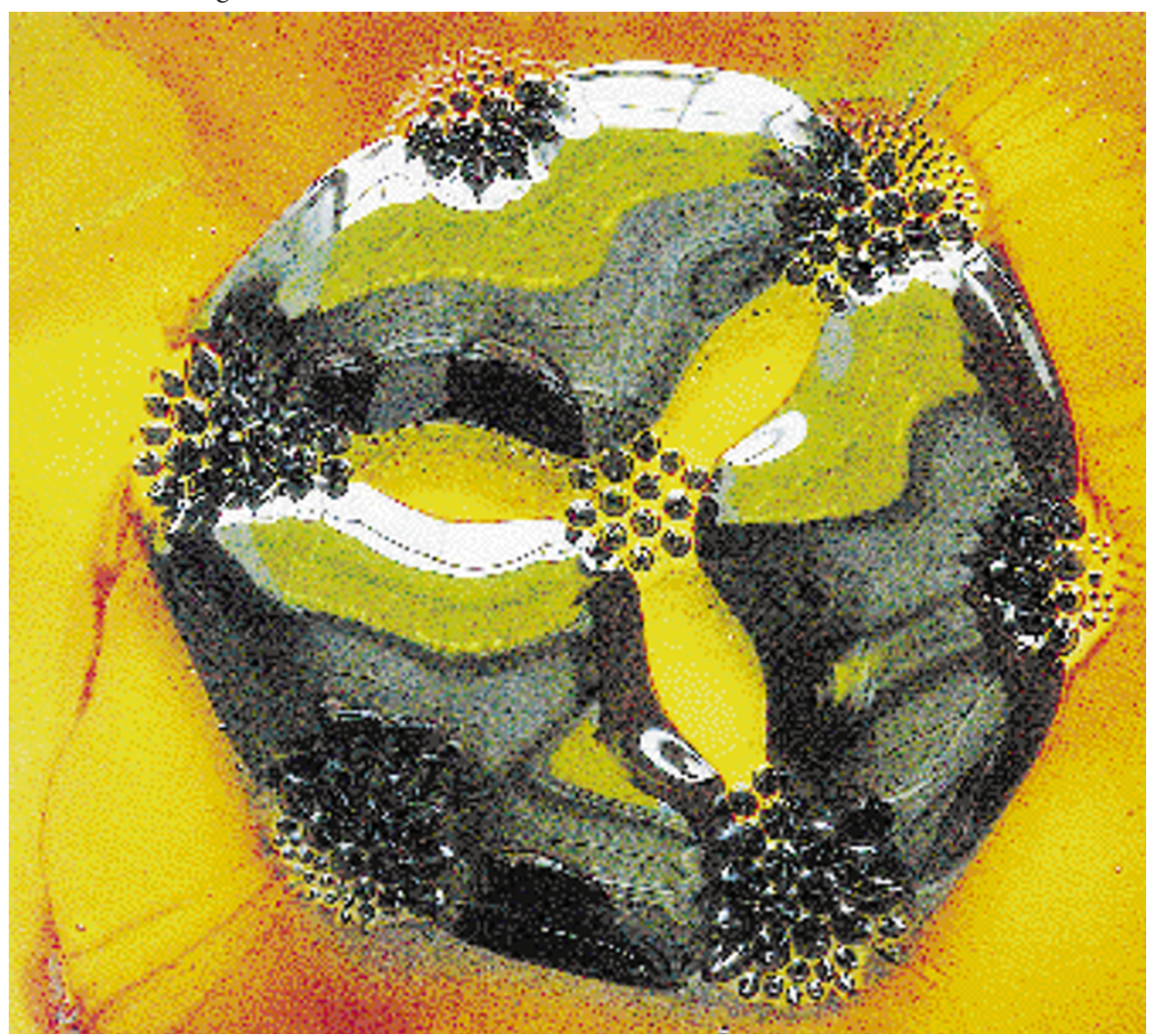

Ferrofluid - "a gryphon in the world of materials: part liquid, part magnet". 